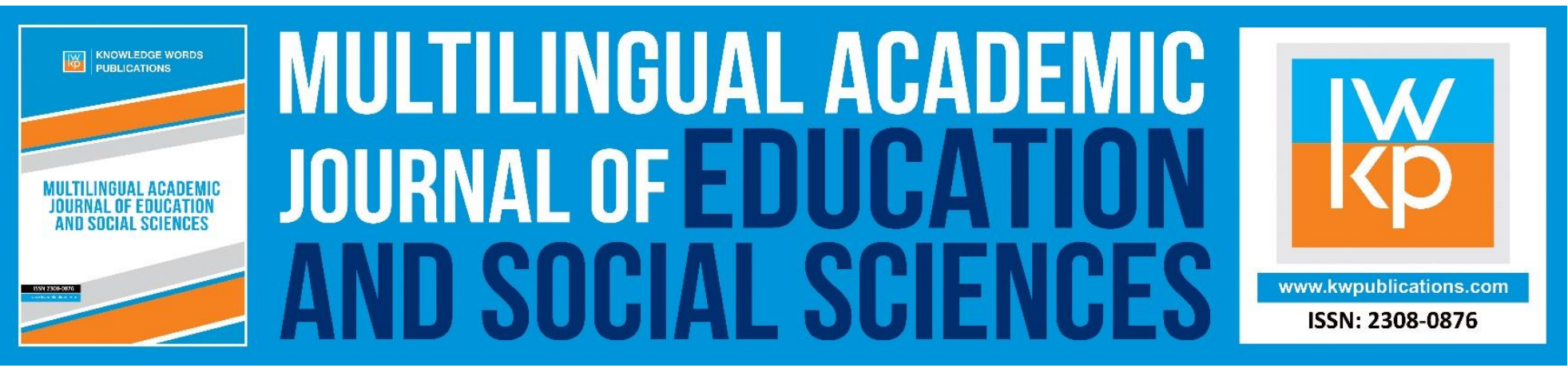

\title{
Virco to Enhance Reading Comprehension
}

\section{Mohamad Subaidi Bin Abdul Samat, Mokhsin Bin Abdul Ghaffar, Revathy Manickam, \& Melor MD Yunus}

To Link this Article: http://dx.doi.org/10.46886/MAJESS/v7-i1/5940

DOI: 10.46886/MAJESS/v7-i1/5940

Received: 11 October 2019, Revised: 14 November 2019, Accepted: 04 December 2019

Published Online: 27 December 2019

In-Text Citation: (Samat, Ghaffar, Manickam, \& Yunus, 2019)

To Cite this Article: Samat, M. S. B. A., Ghaffar, M. B. A., Manickam, R., \& Yunus, M. M. (2019). Virco to Enhance Reading Comprehension. Multilingual Academic Journal of Education and Social Sciences, 7(1), 57-67.

\section{Copyright: (C) The Authors 2019}

Published by Knowledge Words Publications (www.kwpublications.com)

This article is published under the Creative Commons Attribution (CC BY 4.0) license. Anyone may reproduce, distribute, translate and create derivative works of this article (for both commercial and non-commercial purposes), subject to full attribution to the original publication and authors. The full terms of this license may be seen

at: http://creativecommons.org/licences/by/4.0/legalcode

Vol. 7, No. 1, 2019, Pg. 57 - 67

https://kwpublications.com/journals/journaldetail/MAJESS

JOURNAL HOMEPAGE

Full Terms \& Conditions of access and use can be found at https://kwpublications.com/pages/detail/publication-ethics 


\title{
Virco to Enhance Reading Comprehension
}

\section{Mohamad Subaidi Bin Abdul Samat ${ }^{1,4}$, Mokhsin Bin Abdul Ghaffar $^{2,4}$, Revathy D/O Manickam ${ }^{3,4}$, Melor MD Yunus ${ }^{4}$}

Sekolah Kebangsaan Punan, ${ }^{1}$ Sekolah Kebangsaan Batu Keling ${ }^{2}$, Sekolah kebangsaan Jabor ${ }^{3}$, Faculty of Education, Universiti Kebangsaan Malaysia ${ }^{4}$

\begin{abstract}
In Malaysian schools, English is being taught in primary and secondary education for 11 years. One of the most important skills in acquiring language is reading. However, most Malaysian pupils struggle to understand what they are reading and thus fail to make meaning out of their reading when they are reading English texts. Therefore, there is a need to aid the reading comprehension process so that the pupils can make better connection with the text and lessen the cognitive load experienced during reading. This study aims to explore the use of ViRCo (Virtual Reading Comprehension) as a strategy to enable the pupils to comprehend meanings of the reading text in three schools around Malaysia, that are, two rural schools in Johor and Sarawak, Malaysia and a semi-urban school at Pahang, Malaysia. This study was inspired by the theory of Multimedia Learning by Richard Meyer. Kemmis and McTaggart's model of action research is used as a research design for this study. The data was collected via tests before and after the intervention, followed by a questionnaire. The data collected from the tests was analysed and later supported by the questionnaire. The finding shows that there was a significant improvement of mean score from the pre-test to the post-test. As this research had proven effective, it will benefit the teachers to guide their pupils to comprehend the text better and to experience fun learning in reading lesson.
\end{abstract}

Keywords: Virtual Reality, Reading Comprehension, ESL Learner, Multimedia Learning.

\section{Introduction}

English language is the lingua franca, where it is the language that is widely used among the people around the world. However, English language learning in Malaysia has been a constant debate in years. The issue of limited mastery in English language among the learners even after going through 11 years of English language learning is worrying (Kaur, 2006; Jalaludin, Mat Awal \& Abu Bakar, 2008; Musa, Lie \& Azman, 2012). In 2017, to make things worse, the levels of English language proficiency among students and graduates has been a heated debate between the employers where apparently the English language proficiency level does not agree to the students' 11 years of learning the English language (Sandhya, 2017). This has raised a question on whether our Malaysian students are ready to face the 4th Industrial Revolution that is set to 
MULTILINGUAL ACADEMIC JOURNAL OF EDUCATION AND SOCIAL SCIENCES

Vol. 7 No. 1, 2019, E-ISSN: 2308-0876 @ 2019 KWP

create a ripple on the development of the country. The 4th Industrial revolution refers to the change of the way we live where there will be a major advancement in technology such as the Internet of Thing (IOT), Artificial Intelligence (AI) and the automation (Monash University, 2018). Everyone especially teachers should play their roles in this technological era by equipped themselves with skills and knowledge to be align with the changes (Yunus, Salehi, \& Chenzi, 2012).

In English language teaching, there are four main skills that is expected to be learnt and improved; that is, Listening, Speaking, Reading and Writing. Reading can be defined as an 'interactive' process that occurs between a reader and the text which results in automaticity or reading fluency where in this process, the reader interacts dynamically with the text as he or she tries to elicit the meaning (Alyousef, 2006). The Malaysian education system introduces reading especially in English language since the children's early childhood. The importance of reading can be seen when the Malaysian KSSR syllabus emphasised that by the end of the 6 years of primary education, pupils should be able to read and comprehend a range of English texts for information and enjoyment (Kementerian Pendidikan Malaysia, 2014).

Information and communication technology (ICT) have provided a vast opportunity on determining how teachers and students collaborate in teaching and learning in today's world (Yunus, Salehi \& John, 2013). The world of education is constantly changing with the emergence of technology that many ways are being introduced on how to enhance teaching and learning to be effective day by day. The use of ICT facilities such as computers, mobile devices and communication devices with services facilities such as the Internet provides a great platform for the teachers to create a well-thought lessons for the pupils to experience learning at their best (Spawa, Clarvie \& Hassan, 2013; Yunus, Nordin, Salehi, Sun, \& Embi, 2013).

The Malaysian pupils' English language performance is assessed during the Primary School Achievement Test (also known as Ujian Pencapaian Sekolah Rendah)(Ministry of Education, 2015) and assesses on pupils' ability on comprehending and eliciting meaning from a text (Lim, Eng, Mohamed, \& Mohamed Ismail, 2018). Though reading skill is vital for the pupils to have a good score, most Malaysian pupils fail to master the skill well. Previous studies conducted by researchers shows that technology utilisation in the ESL classrooms facilitates pupils in their language learning process which can avoid the problem in learning especially reading lesson (Wiley, 2002). Therefore, this study was conducted to help pupils to understand texts better and to enable them to enjoy reading. This paper revealed a promising result of the use Virtual Reality (VR) as a strategy to improve Year 5 pupils in comprehending a text better in two rural schools located in Johor and Sarawak, Malaysia and a semi-urban school in Pahang, Malaysia. The virtual reading comprehension as an aid for reading comprehension is promising because the data collected through tests and questionnaire revealed the pupils' ability to comprehend the text and answer comprehension question based on the text has been improved. The study aims to explore the effectiveness of Virtual Reality (VR) technology in helping the pupils to comprehend text better.

\section{Literature Review}

\section{Schema and Reading Comprehension}

Reading is a multifaceted cognitive activity that is vital for adequate functioning and for gaining information in current society and requires an integration of memory and meaning construction 
MULTILINGUAL ACADEMIC JOURNAL OF EDUCATION AND SOCIAL SCIENCES

Vol. 7 No. 1, 2019, E-ISSN: 2308-0876 @ 2019 KWP

(Alfassi, 2004). According to Xie (2017), the meaning is not attached to the surface of the language form but depends on the reader's ability to use schema knowledge through both bottom-up and top-down prediction and inference. In reading, the reader's world knowledge schema such as background knowledge, cross-cultural knowledge, the reading structural knowledge is as important as his language knowledge (Rumelhart, 1980). This was also mentioned by Anderson, Reynolds, Schallert \& Goetz (1976) and later supported by Elbro and Buch-Iversen (2013) said that adequate language knowledge, quick activation of word-meaning schemata and the techniques using background schemata to predict and infer are necessary conditions for the reader to read efficiently and failure to activate relevant, existing background knowledge may be a cause of poor reading comprehension. This failure may cause particular problems with inferences that depend heavily on prior knowledge (Elbro \& Buch-Iversen, 2013).

\section{Virtual Reality}

Virtual reality is three-dimensional images, produced by a set of devices and technologies and offer a visual interaction with a virtual environment (Tammie \& Steffen, 1992). Virtual reality helped the user to experience and interact with the environment created through $360^{\circ}$ videos. Visual experience of the virtual reality aided by the sounds and device movement and let the user immerse in the world they never experience before (Borg, 2017). Besides that, the use of virtual reality and the environment contribute to the students' concentration in learning as they will have a better connection with the stimulus and the content. (Merchant et al, 2014). According to Cappello \& Lafferty (2015) teacher should use the virtual reality technology to aid pupils to comprehend complex reading comprehension text and Pilgrim \& Pilgrim (2016) mentioned the use of visual make the ideas more visible or concrete for the students. The study by Yunus, Salehi \& John (2013) also mentioned the use of visual aids helps the students to learn as it raises their curiosity and motivate them to comprehend the lesson.

\section{Multimedia Text and Technology as An Aid for Reading Comprehension}

The research has been based by many journals. One of the studies is the 'Developing Multimedia Text for Reading Comprehension Based on Cognitive Theory of Multimedia Teaching (Alkhasawneh et. al, 2012). This study suggested developing multimedia text for reading comprehension by using Mayer's cognitive theory of multimedia teaching (Mayer, 2010). This has been served as one of a strong bases for our research. Besides that, the findings of this research states that students who use both channels (verbal and pictorial) in reading comprehension text will make the students' achievement in reading comprehension better. This finding supports the premise where the use of multimedia text can help the pupils in reading comprehension. Mayer's findings support the premise where the use of multimedia text will be able to help the students in reading comprehension.

Besides that, in García, Rigo \& Jiménez (2017) study, the researchers aim to see the differences between textual learning and multimedia learning within the context of PLE's (Personal Learning Environment) reading tools and strategies. In the study, the researcher made an analysis of possibility to improve the reading process through multimedia over a school term in two different aspects; one evolutionary with six classroom exercises and one evaluation with a final exercise. The finding of the study indicates that there is a better evolution in students that performed the multimedia dynamic and supported the idea of using multimedia learning as one 
of the methods in reading comprehension. The use of technology might be the reason of students' performance as technology motivate the students to learn in technology integration lesson as shown in the study of Yunus \& Suliman (2014). Another study that related is the study by Abidin, Ping \& Raman (2012) on Using Web-based Resources in Reading Comprehension in a Rural Primary School. The study investigated the use of web-based resources to motivate students in reading comprehension. The results for both instruments shows the students were motivated when promoted in using web-based resources in reading comprehension and it also supported with the finding from Yunus, Lubis, \& Chua (2009) where the students can take control of their learning by using technology or web based activity. Based on the findings, the study recommends that educators adopt and adapt the web-based resources to teach reading comprehension as well as other language skills.

A study by Subbiah and Singh (2003) also highlights the problem of reading comprehension in rural secondary school students in Malaysia as they continue to encounter great difficulties when reading in English even though they have undergone the English Language. The problem mentioned in the study was the same concern highlighted in our study and it is obvious that in the rural areas, English perceive as either the second language or foreign language. Therefore, the problem in reading comprehension among rural school students need to be addressed and good intervention needed to combat the problem.

\section{Methodology}

\section{Research Design}

The study is focusing in using quantitative and plans to employ action research as the basis of the research. Besides that, the research design for this study based from Kemmis and McTaggart model of action research (Kemmis, McTaggart, \& Retallick, 2004). The model proposed to use 4 stages in doing action research such as plan, act, observe and reflect.

\section{a) Plan}

The reading comprehension modules were designed according to the level and aim of the study. The suitable intervention for the problem, materials for pre-test questions and questionnaires were made in advance.

\section{b) Act}

Participants of the study were briefed on the objective and what are they expected to do until the end of the study. The students read a reading text and answer one set of comprehension question as pre-test before tested with another set of comprehension question after intervention introduced. After that, the students answered a questionnaire.

\section{c) Observe}

The progress of the intervention observed through the margin of difference for score between pre-test and post-test. The questionnaire also used as one of the observation tools to monitor the students' opinion on the intervention used in the study. 
MULTILINGUAL ACADEMIC JOURNAL OF EDUCATION AND SOCIAL SCIENCES

Vol. 7 No. 1, 2019, E-ISSN: 2308-0876 @ 2019 KWP

\section{d) Reflect}

Result of the pre-test and post-test is being used as the guideline in reflecting process. The data collected in both instruments including questionnaire are used to determine whether the intervention proposed giving significance changes towards students' reading comprehension skills.

\section{Participant}

Based on this idea, an action research was conducted in one semi-urban school in Pahang, Malaysia (School A) and two rural schools in Johor, Malaysia (School B) and Sarawak, Malaysia (School C). 20 pupils were selected through purposive sampling based on their proficiency level in reading. All the participants were either weak or average in their level of proficiency.

\section{Instruments}

The research design consists of a pre-test and post-test. The tests were conducted to measure pupils' ability in reading comprehension. These tests were in the form of worksheet consists of 8 questions. A questionnaire was given to the participants to answer after the post-test to identify the effectiveness of ViRCo as an aid for reading comprehension.

\section{Procedures}

A pre-test was conducted to measure the participants' ability in reading comprehension without the aid of ViRCo. The pre-test consists of 8 questions based on a reading text. The participants were required to answer the questions in 20 minutes after lesson conducted. The worksheets were collected after they had completed them.

The intervention was carried out on the next day. It was carried out during while-lesson and used as teaching tool to let the participants relate the reading text and visual aids. ViRCo was used to help the participants make connection between what they have read and difficult vocabulary in the reading text. The participants read the text and were given Virtual Reality goggles which let them experienced the event being discussed in the reading text. Then they completed the posttest in similar manner as before. After that, the questionnaires were given to all participants and they answered individually while being guided by the researcher.

\section{Data Analysis}

Quantitative data analysis is used in analyze the data gained from the instruments. Data collected from questionnaire, pretest and posttest are analyzed using SPSS software and were used to compare the mean scores.

\section{Data Analysis and Findings}

A comparison of pre-test and post-test marks were carried out to determine the effectiveness of ViRCo as a tool to improve pupils reading comprehension. Table 1 show the results of pre-test and post-test from all 20 participants from School A, School B and School C. 
MULTILINGUAL ACADEMIC JOURNAL OF EDUCATION AND SOCIAL SCIENCES

Vol. 7 No. 1, 2019, E-ISSN: 2308-0876 @ 2019 KWP

Table 1. Result of Pre-test and Post-test scores

\begin{tabular}{|c|c|c|c|c|}
\hline School & Participants & Pre-test & Post-test & Margin of Difference \\
\hline \multirow[t]{5}{*}{ A } & 1 & 5 & 10 & 5 \\
\hline & 2 & 4 & 9 & 5 \\
\hline & 3 & 5 & 10 & 5 \\
\hline & 4 & 3 & 8 & 5 \\
\hline & 5 & 4 & 9 & 5 \\
\hline \multirow[t]{5}{*}{ B } & 6 & 4 & 7 & 3 \\
\hline & 7 & 4 & 7 & 3 \\
\hline & 8 & 6 & 10 & 4 \\
\hline & 9 & 5 & 9 & 4 \\
\hline & 10 & 6 & 10 & 4 \\
\hline \multirow[t]{10}{*}{ C } & 11 & 7 & 10 & 3 \\
\hline & 12 & 6 & 8 & 2 \\
\hline & 13 & 7 & 9 & 2 \\
\hline & 14 & 5 & 8 & 3 \\
\hline & 15 & 5 & 7 & 2 \\
\hline & 16 & 6 & 9 & 3 \\
\hline & 17 & 7 & 9 & 2 \\
\hline & 18 & 8 & 10 & 2 \\
\hline & 19 & 7 & 10 & 3 \\
\hline & 20 & 6 & 9 & 3 \\
\hline Overal & Mean Score & 5.5 & 9.4 & 3.9 \\
\hline
\end{tabular}

Table 1 shows that participants' progress from pre-test and post-test. Based on the pretest results, it is established that the participants' performance is at intermediate level in answering the comprehension questions before VirCo was introduced as the mean score is at 5.5. After the introduction of ViRCo, the post-test results indicated a significant improvement for the three schools as the mean score increased to 9.4. This result indicated a significant impact of the usage of ViRCo which suggest its effectiveness in aiding pupils to comprehend and contextualize the text better. Pupils were able to answer the comprehension better after the introduction of ViRCo.

Table 2. Paired Samples Test

\begin{tabular}{|c|c|c|c|c|c|c|c|}
\hline & & $\begin{array}{l}\text { Paired } \\
\text { Differences }\end{array}$ & $\mathrm{t}$ & $d f$ & \multirow{2}{*}{$\begin{array}{l}\text { Sig.(2- } \\
\text { tailed) }\end{array}$} & & \\
\hline & & Mean & $\begin{array}{l}\text { Std. } \\
\text { Deviation }\end{array}$ & $\begin{array}{c}\text { Std. Error } \\
\text { Mean }\end{array}$ & & & \\
\hline $\begin{array}{l}\text { Pair } \\
1\end{array}$ & $\begin{array}{l}\text { Pretest } \\
\text { Posttest }\end{array}$ & -3.40000 & 1.14248 & .25547 & -13.309 & 19 & .000 \\
\hline
\end{tabular}

Table 2 shows the results of the paired sample $t$-test where there is a strong evidence $(t=-$ 13.309, $p=0.000$ ) that the use of ViRCo improves the pupils' understanding in reading comprehension. In this data set, it improves marks, on average, by approximately 3 point. This 
MULTILINGUAL ACADEMIC JOURNAL OF EDUCATION AND SOCIAL SCIENCES

Vol. 7 No. 1, 2019, E-ISSN: 2308-0876 @ 2019 KWP

confirmed that the use of ViRCo helps pupils in answering reading comprehension questions. Therefore, the use of ViRCo can enhance the reading comprehension for pupils.

After the post-test of the study, all participants answered a 20-items questionnaire of 3point Likert scale. The questionnaire was used to find out how the participants perception towards reading in general and how the usage of audiovisual aids (ViRCo) has helped them in the reading comprehension. The finding is shown in Table 3 below:

Table 3. Questionnaire Score

\begin{tabular}{cccc}
\hline Statements & 1(NO) & 2(NOT SURE) & 3(YES) \\
\hline 1 & 8 & 1 & 11 \\
2 & 11 & 3 & 6 \\
3 & 5 & 1 & 14 \\
4 & 3 & 2 & 15 \\
5 & 0 & 3 & 17 \\
6 & 2 & 1 & 17 \\
7 & 0 & 4 & 16 \\
8 & 1 & 2 & 17 \\
9 & 0 & 0 & 20 \\
10 & 0 & 3 & 17 \\
11 & 6 & 9 & 5 \\
12 & 8 & 1 & 11 \\
13 & 2 & 4 & 14 \\
14 & 0 & 2 & 18 \\
15 & 0 & 1 & 19 \\
16 & 0 & 3 & 17 \\
17 & 2 & 2 & 16 \\
18 & 0 & 0 & 20 \\
19 & 0 & 1 & 19 \\
20 & 0 & 2 & 18 \\
\hline
\end{tabular}

Based on Table 3, it was found out that all 20 participants agreed on the statement that it is hard to understand the comprehension text if there are difficult words in the text (Item No 18). Besides that, 19 out of 20 participants agreed that audiovisual aid helps them to retell the information that they have read (Item No 15). Next, 19 out of 20 participants agreed that they managed to make connection between the text and the audiovisual aid (Item No 19). Ultimately, it was found that all 20 participants agreed that ViRCo helps them in answering the comprehension questions (Item No 9). Surprisingly, 18 out of 20 participants agreed that the use of ViRCo also helps them to acquire new vocabulary (Item No 20).

Overall, the use of ViRCo as a tool to enhance reading comprehension among the pupils in these three school has had a positive impact. All pupils were able to score better in the post-test compared to the pre-test. The use of ViRCo helps the pupils to create a schema about the text that they are reading as it activates their visual and auditory senses. Furthermore, the pupils also 
MULTILINGUAL ACADEMIC JOURNAL OF EDUCATION AND SOCIAL SCIENCES

Vol. 7 No. 1, 2019, E-ISSN: 2308-0876 @ 2019 KWP

acquired new vocabulary and were able to contextualize that vocabulary because ViRCo aids by providing the audio-visual scaffolding.

\section{Conclusion}

Based on the findings, it can be concluded that ViRCo is a beneficial method to help the pupils in comprehending a text. The participants get to experience what they are reading with the Virtual Reality (VR) experience. It is fun and also motivates the pupils further to comprehend the text as they could relate the text with themselves through the Virtual Reality (VR) experience. The findings are useful for teachers to assist their pupils in comprehending the text that the teacher has introduced in the classroom. The findings have showed a significant increase in pupils' interest towards attempting the reading comprehension questions. Furthermore, the Virtual Reality (VR) box is a very cost-effective material that the teachers can use in the classroom.

\section{Implications}

The result of this research highlights that the pupils are interested to use Virtual Reality (VR) experience as one of their ways to learn English language. The Virtual Reality (VR) experience has enabled the pupils to comprehend the text given to them better during their English language lesson. The Virtual Reality (VR) experience has captivated the pupils' attention to use it during that the pupils' interest will be easily captured and thus enabling them to get the input that the teachers are trying to deliver.

their English language lesson that it significantly increased their interest to learn the English language. Thus, teachers should be actively incorporating digital elements in the classroom so

\section{References}

Abidin, M. J. bin Z., Ping, J. L. S., \& Raman, P. (2012). Using Web-Based Resources in Reading Comprehension in a Rural Primary School. Malaysian Journal of ELT Research, 8(1), 119152.

Alfassi, M. (2004). Reading to learn: Effects of combined strategy instruction on high school students. Journal of Educational Research, 97(4), 171-184.

Alkhasawneh, S., Rahman, F., Ayub, A., \& Daud, S. (2012) Developing Multimedia Text for Reading Comprehension Based on Cognitive Theory of Multimedia Teaching. International Journal of Innovative Ideas, 12(4), 11-19.

Alyousef, H. S. (2006). Teaching Reading Comprehension to ESL / EFL Learners. Journal of Language and Learning, 5(1), 379-380.

Anderson, R. C., Reynolds, R. E., Schallert, D. L., and Goetz, E. T. (1976). Comprehending Discourse (Technical Report No. 12) Urbana: University of Illinois Labortory for Cognitive Studies in Education.

Borg, K. (2017). What Is Virtual Reality And How Is It Going To Change Our Future? Retrieved from https://digitalagencynetwork.com/what-is-virtual-reality-and-how-is-it-going-to-changeour-future/

Cappello, M., \& Lafferty, K. E. (2015). The roles of photography for developing literacy across the disciplines. The Reading Teacher, 69(3). 287- 295. 
MULTILINGUAL ACADEMIC JOURNAL OF EDUCATION AND SOCIAL SCIENCES

Vol. 7 No. 1, 2019, E-ISSN: 2308-0876 @ 2019 KWP

Elbro, C., \& Buch-Iversen, I. (2013). Activation of background knowledge for inference making: Effects on reading comprehension. Scientific Studies of Reading, 17(6), 435-452.

García, J. D., Rigo, E., \& Jiménez, R. (2017). Multimedia and Textual Reading Comprehension: Multimedia as Personal Learning Environment's Enriching Format. Journal of New Approaches in Educational Research, 6(1), 3-10.

Jalaludin, N. H., Awal, M. N., \& Abu Bakar, K. (2008). The mastery of English language among lower secondary school students in Malaysia: A linguistic analysis. European Journal of Social Sciences, 7(2), 106-119.

Kaur, N. (2006). Non-autonomy and low-English proficiency among Malaysian students: Insights from multiple perspectives. Kamisah Ariffin, Mohd. Rozaidi Ismail, Ngo Kea Leng, \& Roslina Abdul Aziz. (Eds.), English in the Malaysian context, 21-34.

Kementerian Pendidikan Malaysia. (2014). Kurikulum Standard Sekolah Rendah. Putrajaya, Malaysia.

Kemmis, S., McTaggart, R., \& Retallick, J. (Eds.). (2004). The action research planner (2nd ed. rev.). Karachi: Aga Khan University, Institute for Educational Development.

Lim, C. K., Eng, L. S., Mohamed, A. R., \& Ismail, M. S. A. M. (2018). Relooking at the ESL Reading Comprehension Assessment for Malaysian Primary Schools. English Language Teaching, 11(7), 146.

Mayer, R. E. (2005). Cognitive theory of multimedia learning. In R.E. Mayer (Ed.), The Cambridge Handbook of Multimedia Learning. New York: Cambridge University Press.

Mayer, R. E., \& Merlin, C. (2010) Wittrock's enduring contributions to the science of learning. Educational Psychologist, 45 (1), 46-50.

Merchant, Z., Goetz, E. T., Cifuentes, L., Keeney-Kennicutt, W., \& Davis, T. J. (2014). Effectiveness of virtual reality-based instruction on students' learning outcomes in K-12 and higher education: A meta-analysis. Computers \& Education, 70, 29-40.

Ministry of Education. (2015). Malaysia - Primary School Achievement Test, Ujian pencapaian sekolah rendah, 1-8.

Monash University. (2018). Gearing up for the Fourth Industrial Revolution. Retrieved November 20, 2018, from https://www.monash.edu.my/news-andevents/pages/latest/articles/2018/ gearing -up-for-the-fourth-industrial-revolution

Musa, N. C., Lie, K. Y., \& Azman, H. (2012). Exploring English language learning and teaching in Malaysia. GEMA Online ${ }^{\circledR}$ Journal of Language Studies, 12(1), 35-51.

Pilgrim, M., \& Pilgrim, J. (2016). The Use of Virtual Reality Tools in the Reading Language-Arts Classroom. Texas Journal of Literacy Education, 4(2), 90-97.

Rumelhart, D. (1980). 'Schemata: The building blocks of cognition'. Comprehension and teaching: Research reviews, 3-26.

Sandhya, M. (2017). Use of English at tertiary level. The Star Online, p. 1. Retrieved from https://www.thestar.com.my/news/education/2017/11/12/use-of-english-at-tertiarylevel/

Spawa, C., Clarvie, M., \& Hassan, F. (2013). " I doesn't know English": Beliefs and Practices in the Teaching of Speaking in ESL Classroom. Pertanika Journal of Social Sciences \& Humanities, 21(2).

Subbiah, R., \& Singh, D. (2003). Problems in Reading Comprehension in English Among Weak Rural Secondary School Students : A Study of Four Rural Secondary Schools in the District 
MULTILINGUAL ACADEMIC JOURNAL OF EDUCATION AND SOCIAL SCIENCES

Vol. 7 No. 1, 2019, E-ISSN: 2308-0876 C 2019 KWP

of Segamat. Unpublished manuscript. Institute of Research, Development and Commercialization, Universiti Teknologi MARA. 1-14.

Tammie, C., \& Steffen, C. (1992). Why virtual reality in education. Retrieved from https://view.officeapps.live.com/op/view.aspx?src=http://people.ucalgary.ca/ ekowch/ 677/oct17/Studentpresoct16_files/Studentpresoct16.ppt

Wiley, D. A. (2002). Connecting Learning Objects to Instructional Design Theory: A Definition, a Metaphor, and a Taxonomy. In D. A. Wiley (Ed.), The Instructional Use of Learning Objects (1st ed., p. 298). Indiana: Agency for Instructional Technology, Association for Educational Communications \& Technology.

Xie, X. (2017). The influence of schema theory on foreign language reading comprehension. The English Teacher, 9, 67-75.

Yunus, M. M., \& Suliman, A. (2014). Information \& Communication Technology (ICT) tools in teaching and learning literature component in Malaysian secondary schools. Asian Social Science, 10(7), 136-152.

Yunus, M. M., Lubis, M. A., \& Chua, P. L. (2009). Language learning via ICT: Uses, challenges and issues. WSEAS Transactions on Information Science and Applications, 6(9), 1453-1467.

Yunus, M. M., Nordin, N., Salehi, H., Sun, C. H., \& Embi, M. A. (2013). Pros and cons of using ICT in teaching ESL reading and writing. International Education Studies, 6(7), 119-130.

Yunus, M. M., Salehi, H., \& John, D. S. A. (2013). Using Visual Aids as a Motivational Tool in Enhancing Students Interest in Reading Literary Texts, 114-117. Retrieved from http://arxiv.org/abs/1305.6360

Yunus, M. M., Salehi, H., \& Chenzi, C. (2012). Integrating social networking tools into ESL writing classroom: Strengths and weaknesses. English Language Teaching, 5(8), 42-48. 